\title{
Evil in Human Nature and its Reflections in Society: With Reference to 'Lord of the
}

\section{Flies' by Golding}

\author{
* Nasim Ullah Khan, Lecturer in English (Corresponding Author) \\ ** Syed Qasim Shah, Lecturer in English \\ *** Muhammad Bilal, Lecturer in English
}

\begin{abstract}
The study investigates the fact that man is evil by nature and this evil surfaces itself when it finds favorable circumstances. These favorable circumstances make themselves available in the removal of societal rules and parental control. Golding connects the evil nature of man to the Original Sin, when Adam did something sinful by violating the command of God in the Garden of Eden. When the boys feel that they are free from parental control and there is no check of the teachers, they start to violate rules on the Island and even go to the extent of killing each other and there is a reversion to barbarism. In the beginning, the boys behave rationally as they have recently been coming from a civilized society but with the time they regress to savagery and barbarism, they feel themselves above the law free from societal disciplines. The study is significantly significant in the sense that it familiarizes the readers with the psyche of human beings who will, consequently, be conscious of their actions. The methodology used for the article is qualitative. The framework used for the paper is thematic. The paper finds out that human being is evil by nature as a result of which there is mischief and evil deeds in society performed by man.
\end{abstract}

Keywords: Human Nature, Evil, Favourable Circumstances, Parental Control, Barbarism. Introduction

Golding's Lord of the Flies is written in the post-World War atmosphere of despair and horror. Golding witnessed human brutality, indiscriminately unleashing itself during the two World Wars. The horrors that he has experienced during the Wars influenced his imagination in such a way as to create a fictional world given to brutal ways of behavior displayed by the children in his novel, Lord of the Flies. Thus, thematically, the novel has its intrinsic connection with wars and violence, whether fought with stones as in primitive societies or with sophisticated technology like drones in our age. Psychologically, wars and conflicts can be attributed to the component of evil in human nature, the topic of metaphysicians and theologians in the world.

Lord of the Flies is set on an island that has its historical roots in Defoe's Robinson Crusoe, Swift's Gulliver's Travels, and The Coral Island by R.M. Ballantyne. On the surface, Lord of the Flies gives us a realistic picture of what modern criminologists call juvenile delinquency. However, at the deeper level, the novel has its thematic connection with the problem of evil as part of the human condition. My reading of the novel shows that some critics focus the novel as a religious allegory, such as Lynn Hynes and his reading of the novel as an artistic extension of the "original sin" as found in Christian metaphysics.

Simon, who is described as a saint or Christ-like figure in the story, represents Christianity while on the other hand Jack and his hunters symbolize paganism and hedonism. A symbolic incident occurs when Simon, the symbol of Christianity, confronts Lord of the Flies- the Devil. The Sow's bloody head on the stake convinces him that the devil is part of man, 'I $\mathrm{m}$ part of you." The message is that the evil spirit is veiled somewhere at the bottom of the human psyche. If moralities, law, and order are removed from society, they will surface themselves.

Analysis

Golding's major concern is with the problem of evil in human nature which, if remains unchecked by higher values of morality and humanity, turns as horribly destructive as displayed in the novel under

* Bacha Khan University Charsadda Email: naseemduke77@ gmail.com

** Bacha Khan University Charsadda Email: qasimshahpmd@gmail.com

*** Bacha Khan University Charsadda 
discussion. He puts young boys on an island where he gives them freedom of will. Initially, the features of civilization stay with them for some time. They conduct assemblies where the right of freedom of speech is bestowed on everyone. The conch shell acquires the status of democracy, discipline, and civilized behavior. Ralph and Piggy put more emphasis on the rules to be followed. They assign the duty of keeping the fire burning to a particular group in the vain hope of being rescued. They build huts to save themselves from the rains and storms and they also construct lavatory, which is a sign of civilization.

The features of civilization start fading away and finally the boys regress to primitivism and savagery. It is Jack who first violates the rules regarding the conch and then, later on, he and his hunters show their irresponsibility by letting the fire go out. The consequence is that they miss a chance of being rescued. They also start playing mock-hunt games in which Jack's hunters pretend to be pigs and others chant and dance around the fire. In a frenzied mood, they kill Simon who brings the news about the reality of the beast. Another act of savagery occurs when Roger - a hunter, drifts a rock onto Piggy - the symbol of rationalism, and kills him. The conch shell- the symbol of democracy and order, is shattered to pieces, and the tyranny of Jack and his hunters takes full control of the island. Later on, the whole island is set on fire to smoke out Ralph. The newly found paradise turns into hell.

In the end, a naval officer is observed for the salvage of the boys. First, he is shocked to see the physical appearance of the British boys but later on after visualizing the atmosphere he says, "A pack of... then that"(Golding, 1958). They are rescued but in reality, they are being taken from this miniature world of savagery to the bigger and crueler world of adults. The protagonist weeps 'for the end...man's heart.'(p. 223)

What we infer from the above discussion is that evil is an integral part of human nature that influences us in different ways if let loose without controls working through laws and morality. The English boys were under social restraint and the check of parents when they were in their country but when they inhabit an exotic island, there is no grown-up to watch them and no social law to check them, they turn into savages.

No sooner did the boys try to plan their rescue than disintegration creeps in them and a group called hunters comes into existence. Slowly and gradually all the boys become the members of this group except Ralph and Piggy. Consequently, they become savages and some of the boys become the victim of their barbarity as Simon and Piggy are murdered on the island. And when, at last, they start to smoke out Ralph by putting the whole of the island on fire, the readers realize that the inner brutal instinct of the boys has come to the surface. "Golding senses that...destruction are enduring". The author makes the readers disillusioned that it is very easy to regress to the original evil nature existent in man if only a favorable climate is provided to him in the shape of the removal of societal rules and parental control. If schoolboys, well-disciplined and innocent can go to the extreme of killing each other when freed from parental control and societal rules, what adults would be doing when they try to maintain world relations?

The island is described as boat-shaped and the children exemplify the human race on their journey through life. This journey is from civilization to primitiveness and savagery.

Both Ralph and Piggy raise the flag of civilization and try to build a disciplined atmosphere. Ralph discovers a conch shell and blows it which helps him to call the scattered boys on the island. It symbolizes democracy, discipline, and civilized behavior. It is a figure for the right to speak and it also regulates the assemblies. Ralph declares after being elected as chief, "we can't...like at school..."(Golding, 1958)

Ralph being a chief tries to enforce this rule and is strongly supported by Piggy. One institution of civilized society is erected.

Ralph proposes to the boys that if they keep a fire burning on the mountain top, they can be rescued soon because the smoke that is rising from the fire could be easily seen by the sailors if any ship passes nearby. Ralph suggests: 'there is another thing...We must make a fire.'(Golding, 1958)

Intellectually enough, they use Piggy's specs to light the fire. It is a sign of their being civilized. Ralph's suggestion to light the fire is approved and it is decided upon that they must keep the fire burning all the time. Therefore Ralph becomes irritated when Jack and his hunters let the fire go out while they keep themselves busy in hunting. Ralph emphasizes the need of the fire as their savior: "the fire...on the island."(Golding, 1958) 
All the boys intensely feel the importance of burning fire on the island and the need to be rescued. Another sign of civilization on part of the boys is the building of huts on the beach.

They want to build shelters like their homes. They require protection from rains and storms. Ralph and Simon both work hard at building huts. Most of the other boys are swimming in the lagoon and are scattered here and there.

Ralph, a symbol of civilization, tries to put everything in right place with his rational mind. He uses his authority to build a lavatory-yet another sign of a civilized society. "There is...use anywhere."(Golding, 1958)

The fruit of the island is often green and causes diarrhea among the boys especially the littluns. They all suffer throughout action. Ralph feels the need for a lavatory so that they can avoid dirt and filth. Simon personalizes the Christian civilized values in himself. He helps the littluns to get fruit from trees because their hands cannot reach the branches. He defends Piggy whenever he becomes the butt of the boys' criticism. He remains loyal to Ralph even though he is originally a member of Jack's choir. Jack also shows his concern about the rules in the beginning. He says; "we've got...do the right things."(Golding, 1958)

The tints of civilization which the English boys bring with them fade away slowly and they regress to savagery. Their inner brutal nature cannot be restrained for long. Without the check of society and the watch of parents, it springs up aggressively and turns the people into savages and animals. Jack and his hunters no longer belong to the world of civilization.

The shell is the emblem of democracy and civilized behavior on the island but, sorry to say, they are ignored more and more by Jack and reminded to him by Piggy again and again who is, in turn, ridiculed by him quite often. As Jack violates the rules as regards the conch on the top of the mountain and Piggy reminds him of the rules, Jack says, "the conch does not count on top of the mountain", but Ralph replies, "We ought to...down there."(Golding, 1958)

Thus while Ralph and Piggy want to follow the rules and support rational behavior, jack violates them. Eventually, the conch is shattered into pieces and then complete chaos prevails on the island when Roger releases the rock from above unto Piggy, killing him. As long as the conch remains alive, democracy and order remain on the island under the authority of Ralph. But as soon as this symbol dies away, democracy also dies with it and order gives way to chaos and barbarity gets hold of the island under the usurper- Jack.

Much emphasis is put on keeping the fire burning and making smoke so that they can be rescued. Jack voluntarily splits up the choir - where the hunters become responsible for keeping the fire burning. But very soon they neglect their duty of keeping the fire burning and keep themselves busy in hunting pigs. Meanwhile, a ship passes nearby without noticing them. They lose the opportunity to be saved from the clutches of savagery. They do not know how much they would have to pay for this negligence. The same fire is used in the final chapter to smoke out Ralph. The forest including the fruit trees and the shelters built by the boys are put on fire. The fire which used to be a source of comfort for the littluns when it burnt near them at night, and which was also a source of rescue, finally becomes the sign of destruction and death; a good servant turns into a bad master. The civilized values start vanishing among Jack and his hunters. Their inner brutal nature is revealed in their physical appearance with painted faces and long hair.

The task of hunting pigs was assigned to Jack and his hunters. They kill pigs to obtain meat but they needlessly indulge themselves in mock-hunt. It confirms the presence of the evil instinct among the boys, especially in Jack and his hunters. It gives vent to the destructive passions and it is dangerous because the more they indulge in these passions the more violent they become. Hunting is considered to be a primitive instinct that still haunts human beings. On one occasion Maurice pretends to be the pig and the boys, forming a circle around him, pretend to beat him, chanting at the same time: 'Kill the pig! Cut her throat! Bash her in!'(Golding, 1958)

The young savages dance wildly and sing around the fire but their behavior is, at this stage, absolutely free of malice or cruelty even though Ralph feels resentful of the way they behave.

Later in chapter 'Shadows and Tall Trees' the hunters have just missed a chance of killing a boar in which Jack receives a slight wound with tusks. To pacify their brutal instinct, the boys organize a game in which Robert pretends to be a pig while the other boys attack and bruise him and chant, 'Kill him! Kill him!' He desperately tries to free himself. Maurice demands a drum to do it 
properly. Later on, Robert says that they need a real pig so that they can kill it; Jack says that they can 'use littluns and kill them.' They have become stone-hearted savages by now.

The third and crueler mock hunt occurs at 'A View of Death' when the boys finish the feast and on Jack's order all the boys start dancing around the burning fire. This time Roger acts as if to be the pig and the hunters form a circle around him hopping and singing; Kill the beast! Cut his throat! Spill his blood!' Roger no more remains the pig and joins the hunters in the circle and the center of the circle becomes empty. Now they cease to be humanized animals but become animalized humans. Abruptly a bleak figure is visible from the forest that is brandishing his hands and calling to the boys. It is Simon bringing some news to them. The frantic boys scream, "The Beast!' Kill the beast!"(Golding, 1958) And Simon, despite his cries of pain and terror, is speared to death. The saintly Christ-like figure, who is about to become their savior, is killed.

Piggy is the most intellectual of the boys on the island. Even Ralph recognizes that Piggy has brains and can think logically. He is the rational force behind Ralph. He tries to adopt a scientific attitude towards the beast rumors and when there is a general fear of ghosts, he says: 'what are we? Humans? Or animals? Or savages? What's grown-ups going to think?'(Golding, 1958)

His specs are stolen by the hunters and then he addresses them and puts questions on them which personify intelligence:

"Which is better... breaking things up?"(Golding, 1958)

In all allegorical interpretations of the novel, Piggy represents intelligence and rationalism. When his specs are stolen, he becomes short-sighted; it means rationalism fades. Finally, when he is killed by Roger, it is the murder of rationalism. Reason is overcome by wickedness and ignorance.

The civilized values are utterly subjugated to savagery and bestiality. All the institutions built by the boys are destroyed. Simon and Piggy are killed. The lesson of conformity and obedience are vanquished by the devilish and hideous impulses which do not come from without but from within the boys. They let them come to the surface. Towards the end of the novel, they set the whole of the island on fire to smoke out Ralph.

'Evil is ineradicable... by the Beast's devotees.'(Golding, 1958)

At the close of the novel, Ralph weeps for the loss of innocence and the darkness of man's heart', in front of a naval officer who comes to rescue them. At this stage, Ralph is no more than a wild pig of the forests that are being hunted for the kill. Shaken by the appearance of the boys and their immorality, chaos, and the disclosure that there have been deaths of some of the boys, the officer articulates his despondency in this "pack of British boys." No possibility is possible for the surprise of the naval officer because the boys have only counterfeited the general drama of the larger world of the adults who try to govern themselves rationally but, sorry to say, the drama ends with the same consequences to kill and hunt. Accordingly, the main objective of the novel is, according to Golding, "to trace the defects of society back to the defects of human nature". The novel ethically demonstrates that a society depends on the moral nature of its individuals, not on any political system. Since these children are the successors of the same deficiencies of human nature which condemned their predecessors, the catastrophe on the island is certain to replicate the real shape of human history.

"They mistake the means for the end, writes Michel-Michot, "The hunters become a savage group of outlaws... deviating further and further from the standards of civilized life that the other group strains to preserve."

For example, in the whole of the novel Roger displays cruelty but in the beginning, "his arm is conditioned by rational society to avoid hitting", when he throws rocks at the littluns, it is only later, when "his emotions overcome his reason that he will lose the boulder that kills Piggy" (Golding, 1958).

In Lord of the Flies, the children who try to enforce a reasonable societal order upon the vital chaos of their nature, are compared to King Pentheus by Baker; their penalty, as in the play, is "bloodshed, guilt, utter defeat of reason".

The larger theme of reason versus emotion goes together with the Dionysian theme. Piggy, who believes strongly in science and technology, represents reason, while Jack and his hunters purely act on wild passion (Golding, 1958). Most characters exhibit qualities of both, however, it is the declaration of their inner conflict that determines what role they end up playing. For example, in the whole of the novel Roger displays cruelty but in the beginning, "his arm is conditioned by rational society to avoid hitting", when he throws rocks at the littluns, it is only later, when "his emotions 
overcome his reason that he will lose the boulder that kills Piggy" (Golding, 1958) In Golding's words, the moral displayed is that "the shape of...respectable". According to Baker, mankind is strictly restricted by the "defect inherent in our species, though man tries to rise above our animal natures, he is inescapably dragged back down."

"Jack is... the dictator, Beelzebub, the Lord of the Flies" (Golding, 1958)

As Hynes explains, "we see with sudden clarity that these murderous savages were civilized children; the point is... that the human propensity for evil knows no limits, not even limits of age, and... there is no Age of Innocence". The second irony is that the "large, efficient, confident" adult, for whose presence Ralph wishes all along, is expected to bring order and justice to the scene; yet "his words show...will not understand". The boys will never be the same, and though the "savages" are restricted by the adult presence, the reader cannot forget or overlook their cruelty and murderous intentions or "the potential evil...permit it".

\section{Conclusion}

The conflicts in the novel are represented as a thematic battle between good and evil. In the beginning, all the characters are essentially good, irresponsible, and cheerful at times: Ralph displays calmness, leadership, and rational thinking (though he often upsets Piggy and ridicules him for his name, that foreshadows the decline to come); Piggy represents knowledge and scientific understanding, which he clings to even through the most hazardous developments; Simon shows sensitivity and acknowledgment, and no fear of the evil; and even Jack, at the first assembly, is civil and agrees his choir to keep the fire burning and hunt for food. Yet once the seed of evil is sowed in the shape of the fear of the "beastie", all these characters eventually fall prey to the evil forces, which is demonstrated by Jack and Roger. When Piggy's glasses are broken, the ability to make fire is also lost - the one helpful quality, a connection to civilization. The fire has a dual purpose: in good hands, it provides heat, cook food, and the hope of rescue, but in evil hands, its vicious power is released and sets the forest on fire, first by accident, then deliberately when Jack tries to smoke Ralph to death. Only Simon knows the reality about the beast and when he wants to inform the other boys, he is speared to death in a mock hunt. After Piggy is bulldozed by Roger by releasing a big stone unto him, there left none to counsel Ralph, and only the timely intrusion of the naval officer saves him from becoming the dark force's next target. And Jack, who is out and out evil, is also overcome by it, because he too, cannot organize its confusion. Thus, everyone yields to the urge of the beast within; and so far the characters are very young in the novel, we cannot hold them responsible for their defects in the society that has provided them with education.

\section{References}

Aldouri, Hussien, Awfa (2011). "Understanding of Humanity: A Study in William Golding's Lord of the Flies" Tikrit University Journal for Humanities. Vol. 18. No.6, pp, 75-88.

Babb, Howard. (1970) the Novels of William Golding. Columbus: The Ohio State University Press.

Baker, J. R. (1988). Why It's No Go. Boston: G.K Hall and Co.

Crawford, Paul. (2002). Politics and History in William Golding: The World Turns Upside Down. USA, University of Missouri Press.

Conybeare, F.C.(1898) The Testament of Solomon, The Jewish Quarterly Review, Vol. 11, No. 1.

Dickson, Lorinda, Larry. (1990).The Modern Allegories of William Golding. USA: University of South Florida.

Dick, Bernard F(1987). William Golding: Revised Edition. Boston: Twayne Publishers.

Elizabeth, Mary. (1999).Lord of the Flies: A Teaching Guide.

Fitzgerald, John F. and John R. Kayser(1992). Golding's Lord of the Flies: Pride as Original Sin. Studies in the Novel, pp, 78-88

Golding, W.(1997)Lord of the Flies as Fable, Readings on Lord of the Flies. London Ed. Bruno Leone, Sand Diego, Green Haven Press. Pp, 88-97.

Golding, W. (1958). Lord of the Flies. London: Faber and Faber.

Kinkead-Weekes, Mark, and Ian Gregor(1967). William Golding: a critical study. London: Faber and Faber.

Lynn Hynes, Samuel. (1968). Essays on Modern Writers, London, Columbia University Press.

Michel-Michot, Paulette (1996). The Myth of Innocence. Revuedes Langues Vivantes, Vol. 28. Discovering Authors. Vers. 2.0. CD-ROM. Detroit: Gale.

Woodward, Kathleen(1997). The Case for Strict Law and Order: Readings on Lord of the Flies. Ed. Bruno Leone. Sand Diego: Green Haven Press, pp, 88-97. 